Revista Eletrônica Geografar, Curitiba, v. 2, Resumos do VI Seminário Interno de Pós-Graduação em Geografia, p. 36-36. Junho/2007

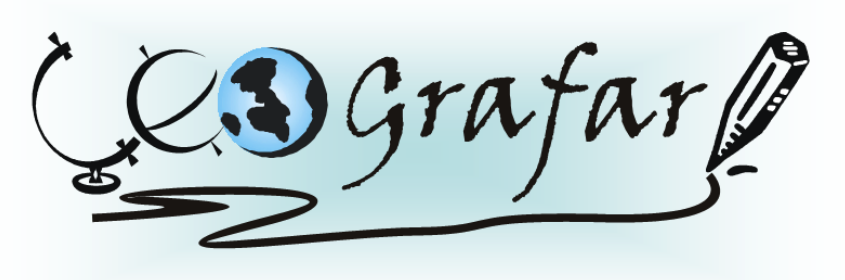

Revista Eletrônica do Programa de Pós-Graduação em Geografia - UFPR

\title{
GEOGRAFIA DA INOVAÇÃO NO ESTADO DO PARANÁ: UMA LEITURA A PARTIR DAS AGLOMERAÇÕES PRODUTIVAS
}

\section{JACKSON TEIXEIRA BITTENCOURT ${ }^{1}$}

Os primeiros modelos teóricos de localização industrial datam do início do século XX e sem dúvida a principal obra sobre a importância da aglomeração produtiva foi a de Marshall quando conceituou os distritos industriais. Com o esgotamento do regime de acumulação fordista, iniciou-se a transição para um novo paradigma produtivo, o pósfordista, obrigando as indústrias a efetuarem alterações em suas estruturas produtivas, dando origem a novos espaços industriais, resgatando e reestruturando o processo de aglomeração produtiva. Com isso, uma das questões relevantes na literatura contemporânea da geografia econômica passou a ser os arranjos produtivos locais (APLs), compreendidos como indutores do desenvolvimento regional. É importante observar que os APLs apresentam diferentes graus de desenvolvimento, logo seu potencial econômico e social se dá de forma diferenciada no espaço. Entretanto, por apresentarem sinergias em conseqüência das economias de aglomeração, provocam significativos impactos no que diz respeito às novas formas de produção, desencadeando um processo de vantagens competitivas para o desenvolvimento da inovação tecnológica tanto em produtos quanto em processos, mesmo em suas configurações mais incipientes. Neste sentido, é objetivo deste projeto compreender as aglomerações produtivas no intuito de classificá-las segundo sua importância para a atividade que desenvolve e para a região onde está inserida, bem como medir sua capacidade de inovar e engajar-se numa dinâmica de internacionalização produtiva analisando seus efeitos no espaço, estabelecendo uma tipologia que forneça critérios para definição de seus estágios. Além disso, é importante salientar que o levantamento e a identificação das aglomerações ocorrerem de formas distintas e muitas vezes singelas, o que demonstra um vasto campo para novas pesquisas e o desenvolvimento de novos modelos.

Palavras-Chave: Indústria, Arranjo Produtivo Local, Desenvolvimento Regional.

'Doutorando em Geografia - UFPR - email:jackson.bittencourt@uol.com.br Orientadora: OLGA LÚCIA C. FIRKOWSKI DE FREITAS 